\title{
The Manufacture of High-Density Woodceramic through the Secondary Carbonization*1
}

\author{
Seung Won $\mathrm{Oh}^{* 2}$
}

\begin{abstract}
A repeated impregnation and carbonization process was performed to prepare high-density woodceramics using MDF. The physical properties were estimated to further confirm morphologically structurally occurred changes of one-time and two-time phenolic resin treated and carbonized woodceramics. As compare onetime and two-time carbonized woodceramics, the increasing rate of weight and density declined after second carbonization as the resin impregnation ratio grew higher, and when the resin impregnation ratio was 40 percent, the weight and density of the second carbonization increased more than in the first step by $20.5 \%$ and $33.9 \%$ respectively which were the highest rates.
\end{abstract}

Keywords : MDF, carbonization, resin impregnation, woodceramics

\section{INTRODUCTION}

Woodceramics are porous carbon materials produced by high temperature carbonization of woody materials impregnated with phenol-formaldehyde (PF) resin. The useful properties include low density, hardness, and corrosion resistance. They process far-infrared ray emission and thermal characteristics. In addition, they are expected to be used as new material for industrial purpose because they have a woody structure (Hokkirigawa et al., 1996; Oh, 2005; Oh and Byeon, 2006; Oh et al., 2000; Okabe et al., 1996; Suda et al., 1999).

The properties of woodceramics are affected by a variety of factors such as the density of the wood or wood-bases materials, the carbonizing temperature, the temperature rise rate, and the cooling temperature. Moreover, resin impregnation ratio has an important influence on the property of woodceramics, converting the material into glassy carbon during the process of carbonization.

Therefore, for the development of various applications of woodceramic, it is required to reform its intensity as much as it can be put to practical use. This is intended as a basic study of the manufacture of high-density woodceramic. For this study, first of all, MDFs (medium-density fiberboards) were impregnated in liquid phenolic resin by the resin impregnation ratio, and

* 1 Received on December 11, 2012; accepted on March 2, 2013

* 2 Department of Wood Science and Technology, Chonbuk National University, Korea

† Corresponding author : 교신저자 메일주소 누락 
carbonized at a high temperature. Through this process, the first woodceramic was made, and then the impregnation and carbonization steps were repeated, so that high-density woodceramic was made.

In this way, we have tried to find basic data to develop new uses for woodceramic by investigating the physical properties of woodceramic made by this method.

\section{MATERIALS and METHOD}

\subsection{Resin Impregnation and Carbo- nization}

This research used medium density fiberboard (MDF)-density, $0.80 \mathrm{~g} / \mathrm{cm}^{3}$; UF resin content, $10 \%$-made of radiate pine for forming woodceramics. Phenol resin (KDP-L777, Kolon chemical Co. Ltd.: solid 52\%; SG 1.025; viscosity 45 to $65 \mathrm{cps}$; and gelation time $86 \mathrm{sec}$.) was used for impregnation. MDF pieces, 12 by 12 by $1.2 \mathrm{~cm}$ in size, were placed in a decompression impregnator that contained liquid phenolic resin, and impregnated at 1 atmospheric pressure, with the resin impregnation ratio range from 40 to 70 percent.

After impregnation, the specimens were put into a dryer for 8 hours at $60^{\circ} \mathrm{C}$, and 10 hours at either $100^{\circ} \mathrm{C}$ to $135^{\circ} \mathrm{C}$ for drying and hardening, respectively. The material was then carbonized at $650^{\circ} \mathrm{C}$ according to the phenol resin impregnation by using a vacuum sintering furnace (KOVAC KSF-220V). The experiment was conducted by subjecting the sample to a temperature rise rate of $5^{\circ} \mathrm{C} / \mathrm{min}$. until researching the target temperature, maintaining the sample at the target temperature for 2 hours, and then cooling the sample at a cooling rate of $5^{\circ} \mathrm{C} / \mathrm{min}$. In order to make a highly density woodceramic, the same method as was used in making the first carbonized woodceramic was used.
The woodceramic was reimpregnated in liquid phenolic resin, and it was dried, hardened, and carbonized at $650^{\circ} \mathrm{C}$ again, from which the second carbonized woodceramic was made.

\subsection{Measurement and SEM Obser- vation}

Ten specimen from each of MDFs-the raw materials, the first carbonized woodceramic, the second impregnated woodceramic, and the second carbonized woodceramic were selected according to each condition, and humidified, and then their size and weight were measured. Their changes in size, weight, and density were investigated. Also, the pictures of the condition of the sections both the first and second carbonized woodceramic were taken with the acceleration voltage of $10 \mathrm{kV}$, W.D. (working distance) $20 \mathrm{~mm}$ using a SEM (Scanning Electron Microscope) in order to make an observation on the changes in tissue of their sections.

\section{RESULTS and DISCUSSIONS}

\subsection{The Physical Properties of the First Carbonized Woodceramic}

According to the resin impregnation ratio of the first carbonized woodceramic, Figs. 1 to 3 show, linear shrinkage and thickness shrinkage, weight loss, and its changes in density. In terms of the linear shrinkage decrease, it decreased as the resin impregnation ratio increased, showing $20.8 \%$ in 40 percent, $19.7 \%$ in 60 percent, and $18.5 \%$ in 70 percent respectively. Meanwhile, the thickness shrinkage decreased after carbonization as the resin impregnation ratio grew higher, showing $28.6 \%$ in 40 percent, $25.3 \%$ in 60 percent, and $22.4 \%$ in 70 percent respectively, which was higher than the rate of decrease in length as a whole. 
The Manufacture of High-Density Woodceramic through the Secondary Carbonization

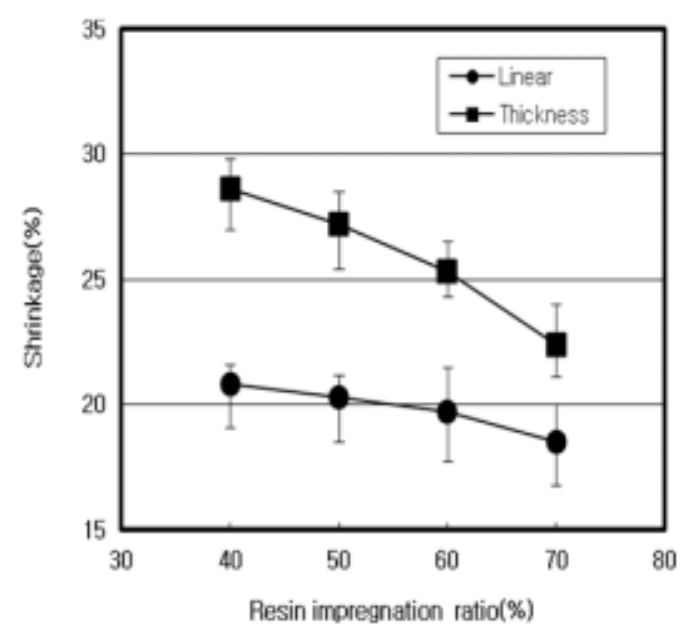

Fig. 1. Shrinkage of woodceramics after first carbonization according to the resin impregnation ratio.

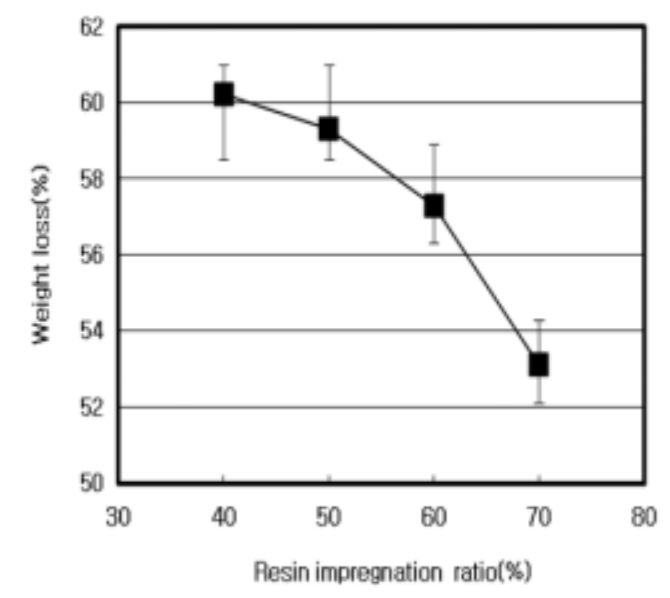

Fig. 2. Weight loss of woodceramics after first carbonization according to the resin impregnation ratio.

The weight loss also reduced as the resin impregnation ratio became higher, showing $60.2 \%$ in 40 percent, $57.3 \%$ in 60 percent, and $53.1 \%$ in 70 percent respectively. In terms of the changes in density, as shown in Fig. 3, it grew higher after carbonization as the resin impregnation ratio increased, showing $0.56 \mathrm{~g} / \mathrm{cm}^{3}$ in 40 percent,

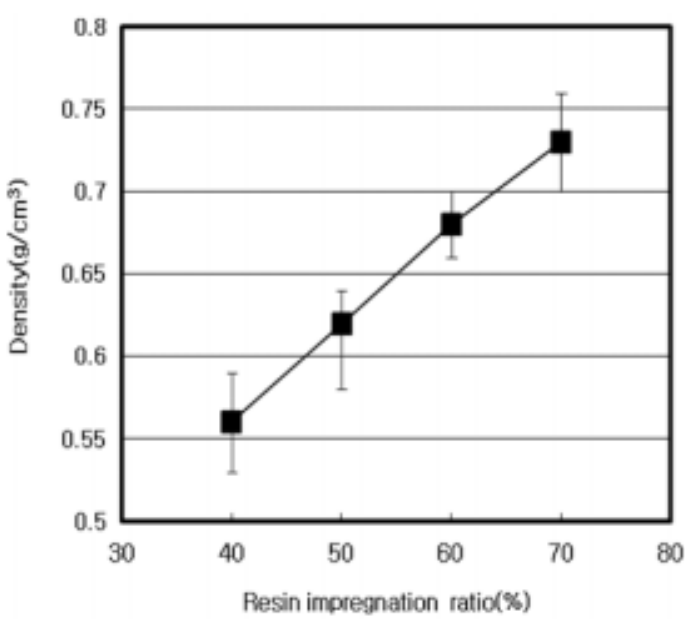

Fig. 3. Density of woodceramics after first carbonization according to the resin impregnation ratio.

$0.68 \mathrm{~g} / \mathrm{cm}^{3}$ in 60 percent, and $0.73 \mathrm{~g} / \mathrm{cm}^{3}$ in 70 percent respectively.

Judging from the above, that was because large amounts of phenolic resin in wood cell walls and lumens converted to glassy carbon through its carbonization, strengthening woody cells. In this study, however, density values after carbonization were somewhat smaller than the ones in the results of other researchers, which seems to be caused by the differences in the properties and manufacturing conditions of woody raw materials and resin.

\subsection{The Physical Properties of the Second Carbonized Woodceramic}

Figs. 4 to 6 show, by the resin impregnation ratio of the second carbonized woodceramic, the linear shrinkage, thickness shrinkage, weight loss, and density. The sample of the second carbonized woodceramic decreased in its length, thickness, and weight as compared with the one before the second carbonization.

The linear shrinkage of the first carbonized 


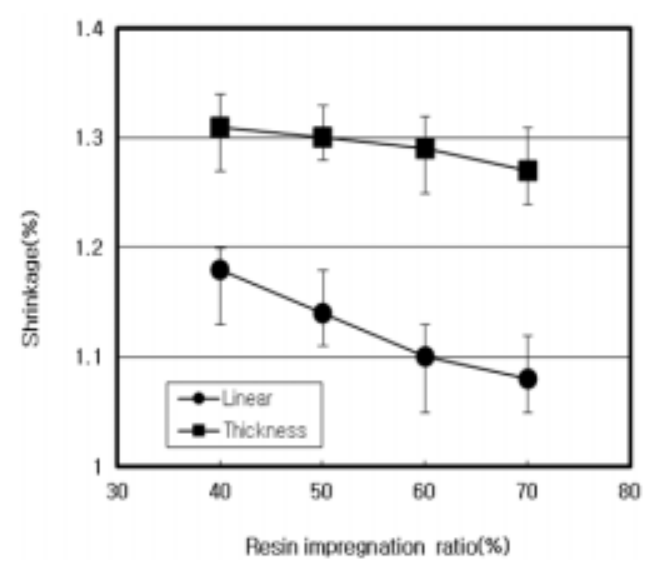

Fig. 4. Shrinkage of woodceramics after second carbonization according to the resin impregnation ratio.

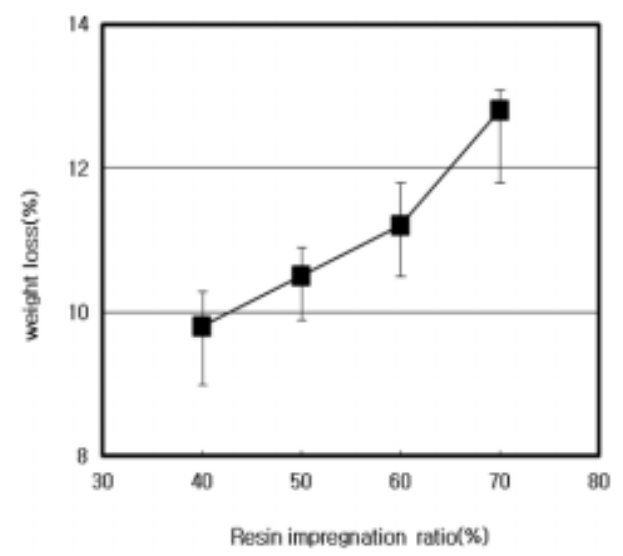

Fig. 5. Weight loss of woodceramics second carbonization according to the resin impregnation ratio.

woodceramic made with the resin impregnation ratio of 40 percent showed $1.18 \%$, which was similar to that of 60 percent and 70 percent, showing $1.10 \%$ and $1.08 \%$ respectively. It coincided with the thickness shrinkage which resulted in $1.31 \%, 1.29 \%$, and $1.27 \%$ in the resin impregnation ratio of 40 percent, 60 percent, and 70 percent respectively.

But the weight loss slightly rose from $9.80 \%$,

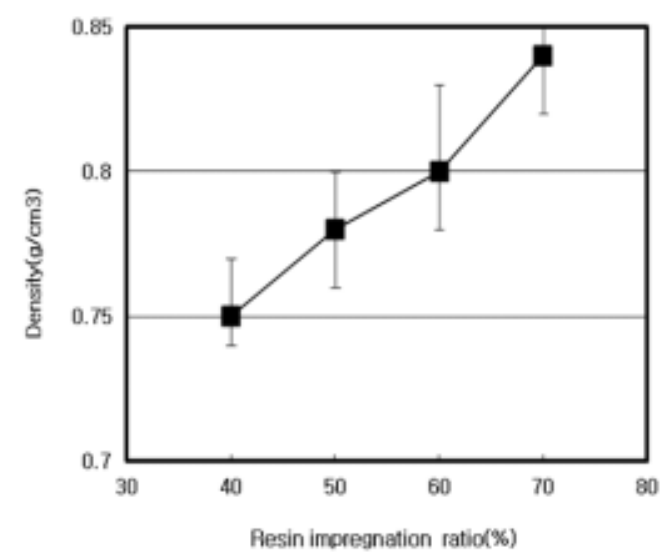

Fig. 6. Density of woodceramics after second carbonization according to the resin impregnation ratio.

$11.21 \%$, to $12.80 \%$ in the resin impregnation ratio of 40 percent, 60 percent, and 70 percent respectively, and its density, shown in Fig. 6, slightly increased with the increase of the resin impregnation ratio, from $0.75 \mathrm{~g} / \mathrm{cm}^{3}$ in 40 percent, $0.80 \mathrm{~g} / \mathrm{cm}^{3}$ in 60 percent, to $0.84 \mathrm{~g} / \mathrm{cm}^{3}$ in 70 percent.

Fig. 7 and 8 show the comparison, in terms of the increasing rate of weight and density by the resin impregnation ratio, between the first carbonized woodceramic and the second carbonized woodceramics which was impregnated with resin and carbonized. After reimpregnation, the weight and density of woodceramic significantly increased as compared with the first carbonized one, but its increasing rate of weight grew lower as the resin impregnation ratio was getting higher, showing $20.5 \%$ in $40 \%, 16.2 \%$ in 60 percent, and $14.3 \%$ in 70 percent.

It is judged from this that the first carbonized woodceramic having a lower resin impregnation ratio had a lower density, followed by the reimpregnation with a high quantity of resin, and it was changed into glassy carbon during the second carbonization, making its weight increase.

The increasing rate of density reduced as the 
The Manufacture of High-Density Woodceramic through the Secondary Carbonization

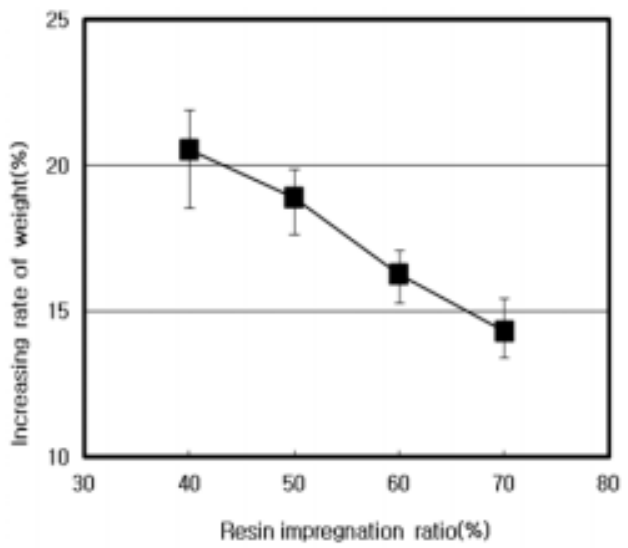

Fig. 7. Increasing rate of weight after second carbonization according to the resin impregnation ratio.

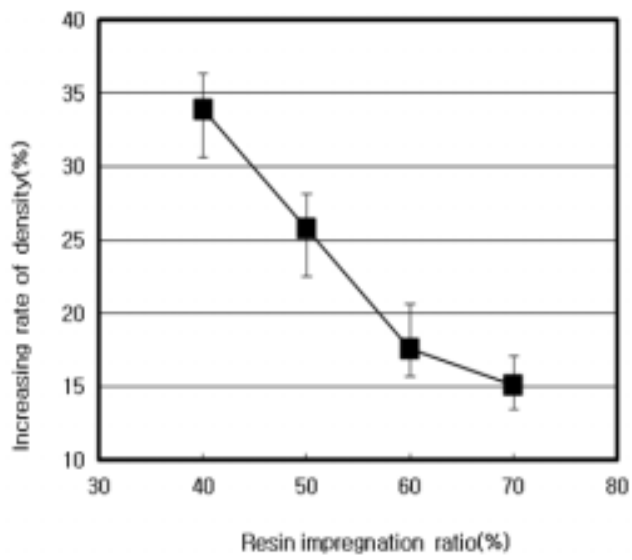

Fig. 8. Increasing rate of density after second carbonization according to the resin impregnation ratio.

resin impregnation ratio was getting higher, showing $33.9 \%$ in 40 percent, $25.8 \%$ in 50 percent, and $15.1 \%$ in 70 percent. We can also judge from this tendency, as the increasing rate of, that: there were many pores in the first carbonized woodceramic which has a lower density because of a low resin impregnation ratio in the first impregnation, and a large quantity of resin was infused into them during the second impreg-

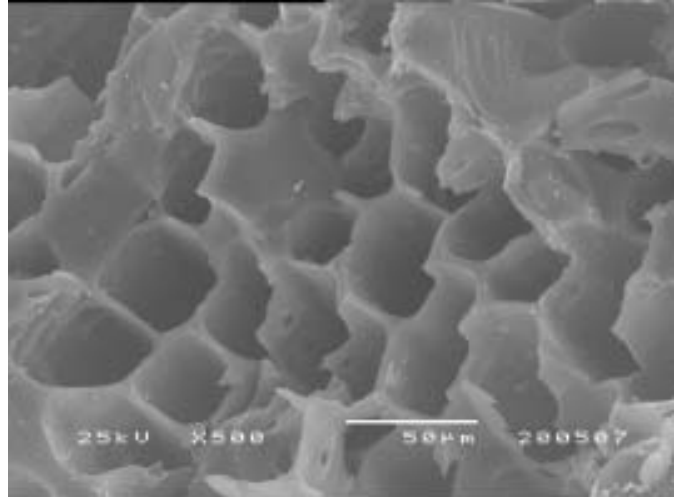

First carbonization

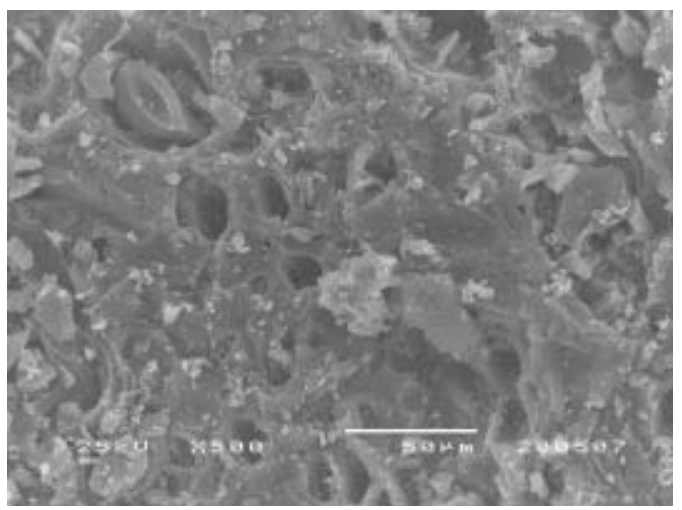

Second carbonization

Fig. 9. Scanning electron micrographs of woodceramics in cross section by 50 percent resin impregnation at $650^{\circ} \mathrm{C}(500 \times)$.

nation, which acted as an effect for the increase in density after carbonization.

In order to observe the variations in tissue of the first and second carbonized woodceramic, an impregnation board having the resin impregnation ratio of 50 percent was reimpregnated with the woodcermic that had been carbonized at $650^{\circ} \mathrm{C}$ at first, and it was carbonized again at the same temperature. The observations of the section of this woodceramic were followed by a scanning electron microscope, and the results appear in Fig. 9. As stated above, the second carbonized woodceramic, in contrast to the first carbonized 
one, increased in its weight because the first carbonized woodceramic was reimpregnated with resin which was infused into its pores. In the process of the second carbonization, the resin was changed into glassy carbon, existing in tracheid lumens, so there were a small number of pores, revealing elaborate tissue. Therefore this glassy carbon was the factor in a density increase after the second carbonization.

These results lead us to the conclusion that it is also effective to carbonize the woodceramic secondarily by reimpregnating the first carbonized woodceramic so that we can make high-density woodceramic. Besides, we have tried a third carbonization after third impregnation in a preparatory experiment, but it is difficult to infuse re$\sin$ in the process of impregnation, bringing about cracks on the samples. Now the manufacture of high-density woodceramic remains as a matter to be considered further in consideration of the diversification of raw materials, the impregnation methods, and the selection of resin.

\section{CONCLUSIONS}

In this study a basic research of the manufacture of high-density woodceramic, the first carbonized woodceramic made by the resin impregnation ratio was impregnated and carbonized secondarily, and the investigation of the physical properties of the woodceramic was conducted.

The results were as follows: As for the first carbonized woodcermic, as the resin impregnation ratio increased, the linear shrinkage, thickness shrinkage, and weight loss declined, while its density became higher. The second carbonized wooderamic showed a linear swelling and thickness swelling as the resin impregnation ratio was getting higher, while increasing rate of density decreased.
When the resin impregnation ratio was 70 perent, the second carbonized woodceramic reached the highest level in the linear shrinkage and thickness shrinkage while the weight loss and the density increased with an increasing resin impregnation ratio.

The comparison between the first and second carbonized woodceramic represented that the increasing rate of weight and density declined after second carbonization as the resin impregnation ratio grew higher, and when the resin impregnation ratio was 40 percent, the weight and density of the second carbonization increased more than in the first step by $20.5 \%$ and $33.9 \%$ respectively which were the highest rates.

\section{REFERENCES}

1. Hokkirigawa, k., T. Okabe, and K. Saito. 1996. Wear properties of new porous carbon materials: woodceramics. J. of Porous Materials 2: 229 235.

2. Oh, S. W. 2005. Properties of woodceramics obtained by high temperatures and phenolic resin impregnation. Forest Products J. 55(9): 27 30 .

3. Oh, S. W and H. S. Byeon. 2006. Far-infrared ray emission and electrical properties of woodceramics manufactured with thinned logs. Forest Products J. 55(7/8): 29 32.

4. Oh, S. W, T. Okabe and T. Hirose. 2000. Manufacturing characteristics of woodceramics from thinned small logs (II)-Dimensional change, weight change and compression strength. Journal of the Korean Wood Science and Technology 28(4): $56 \sim 60$.

5. Okabe, T., K. Saito and K. Hokkirigawa. 1996. New porous carbon material woodceramics. J. of Porous Materials 2, 207 213.

6. Suda, T., N. Kondo, T. Okabe, and K. Saito. 1999. Electrical properties of woodceramics. J. of Porous Materials 6: $255 \sim 258$. 